\section{The FOMC in 1997: A Real Conundrum}

\author{
Peter S. Yoo
}

D

r. Pangloss might have described the performance of the U.S. economy during 1997 as "the best of all possible worlds," and in many respects he would have been correct. The economy grew rapidly throughout the year while most measures of inflation fell steadily. More important, the strength of the economy generated visible benefits: nearly 3.2 million new jobs, a higher average real wage, and a Federal government's budget that was within whispering distance of balance.

Clearly, Dr. Pangloss was not a practitioner of the dismal science, otherwise he would have found 1997 a trying time. Throughout the year, economists struggled to identify the factors that produced strong real growth and lower-than-expected inflation. This was especially important for the members of the Federal Open M arket Committee (FOMC) because traditional signals of inflationary pressures- monetary aggregates and strength of the real economyprovided little guidance. The performance of the U.S. economy during 1997 indicated aggregate supply factors were at play as well. Thus the FOMC had to sort through aggregate demand and supply factors to determine inflationary pressures.

Some economists speculated that the U.S. economy had entered a new era of rapid sustainable growth. Low inflation and strong growth during 1996 and 1997 fueled such speculation. If true, any factors that produced such outcomes were long lived and required a different set of policy responses. Such considerations likely motivated the questions, "W hat is behind the good performance of the economy?" and "Will it persist?" during Alan Greenspan's Humphrey-Hawkins testimony in July 1997.

\author{
Members of the Federal Open Market Committee in 1997 \\ Alan Greenspan, Chairman of the Board of Governors of the Federal Reserve System and of the FOMC \\ Alice M. Rivlin, Vice Chair of the Board of Governors of the Federal Reserve System \\ Edward W. Kelley, J r., Governor of the Federal Reserve System \\ Susan M. Phillips, Governor of the Federal Reserve System \\ Laurence H. Meyer, Governor of the Federal Reserve System \\ Roger W. Ferguson, J r., * Governor of the Federal Reserve System \\ Edward M. Gramlich,* Governor of the Federal Reserve System \\ William J. MCDonough, Vice Chair of the FOMC and President of the Federal Reserve Bank of New York \\ J. Alfred Broaddus, Jr., President of the Federal Reserve Bank of Richmond \\ Michael H. Moskow, President of the Federal Reserve Bank of Chicago \\ Jack Guynn, President of the Federal Reserve Bank of Atlanta \\ Robert T. Parry, President of the Federal Reserve Bank of San Francisco
}

*Drs. Ferguson and Gramlich took office on November 5, 1997, and their first FOMC meeting was on November 12. 


\section{Figure 1}

\section{Real GDP}

Percent Change From Year Ago

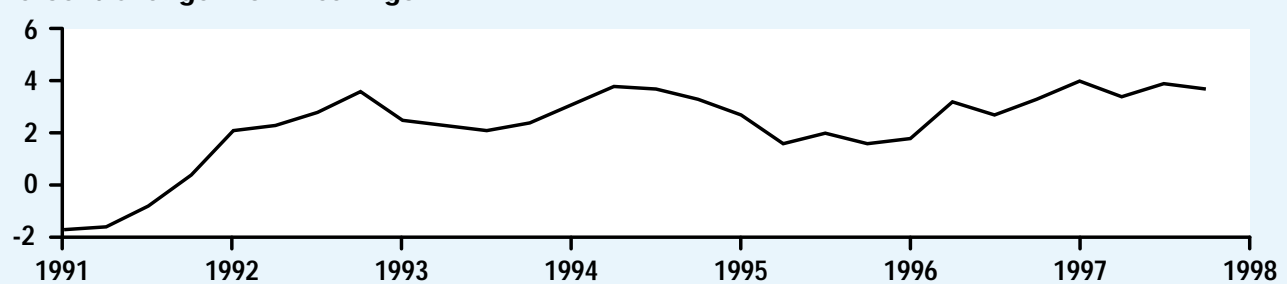

Consumer Price Index

Percent Change From Year Ago

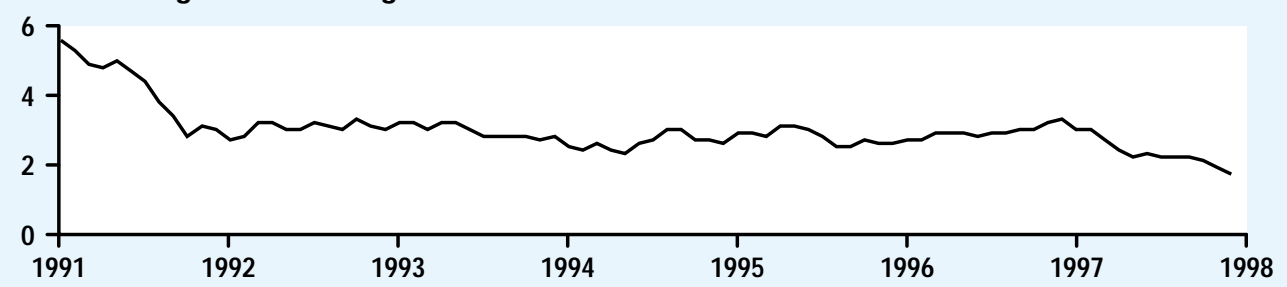

Civilian Unemployment Rate

Percent of Labor Force

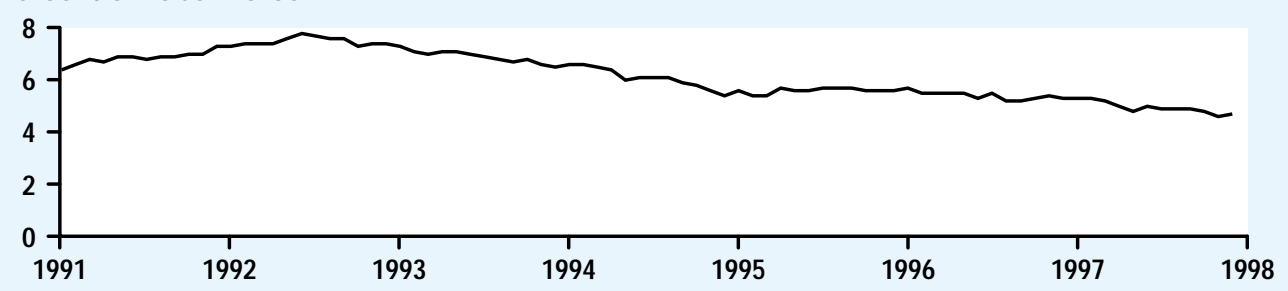

Nonfarm and Manufacturing Output Per Hour Percent Change From Year Ago

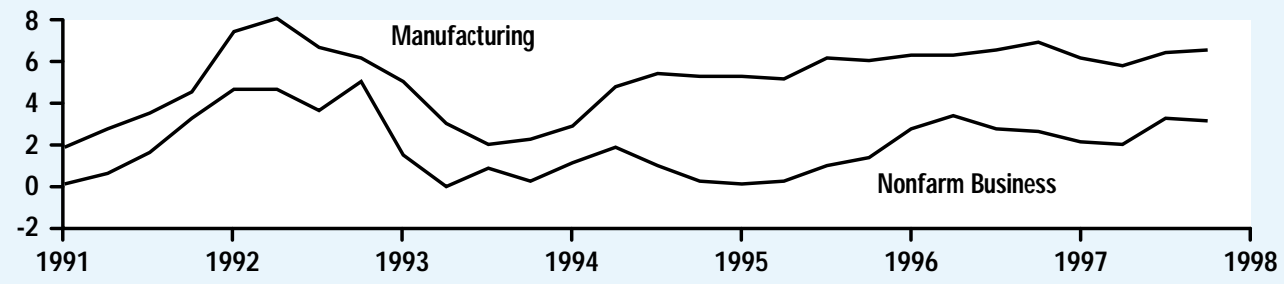

\section{Employment Cost Index \\ Percent Change From Year Ago}

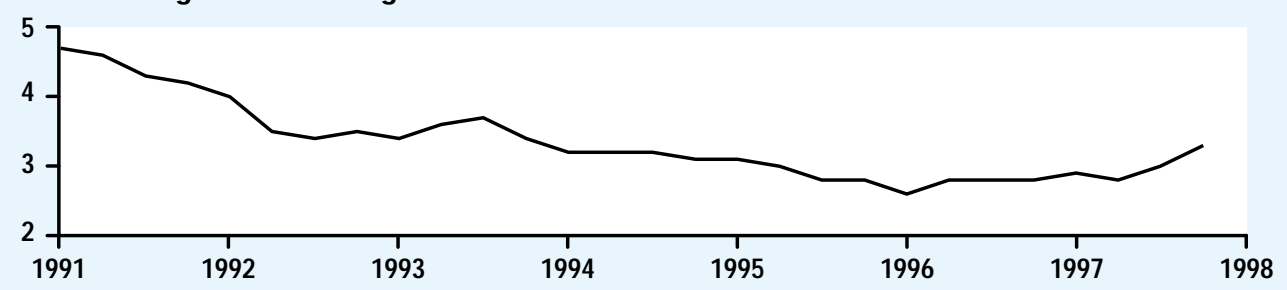




\section{Figure 1 continued}

\section{Real Private Fixed Investment}

Percent of Real GDP

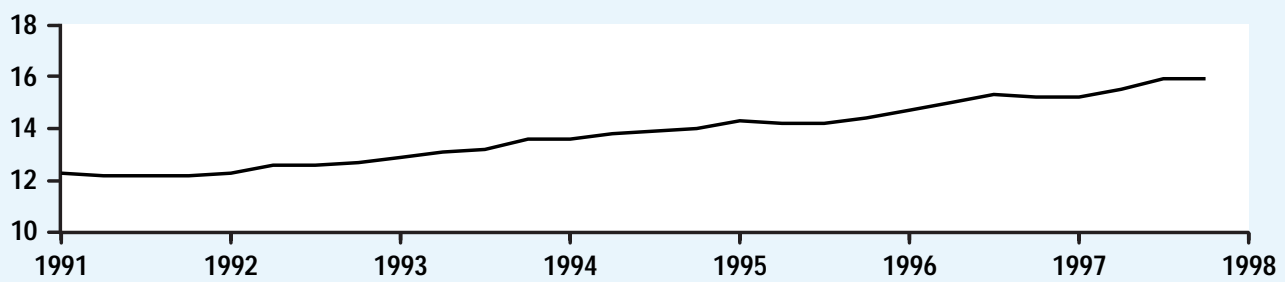

Total Returns on S\&P 500

Percent Change From Year Ago

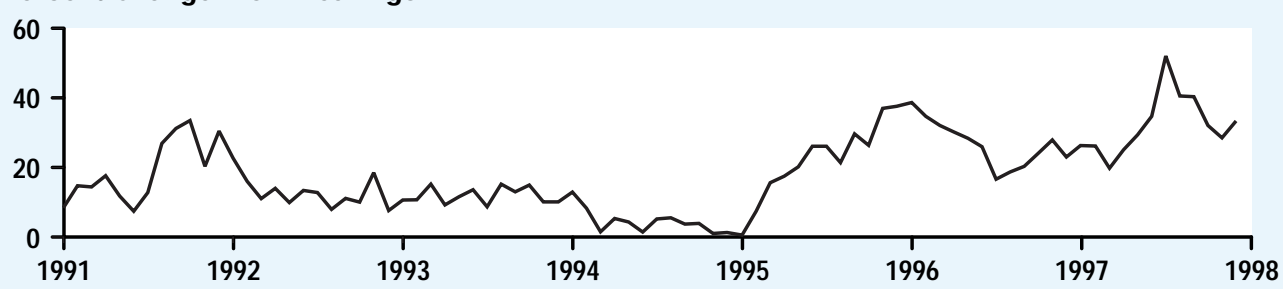

Selected Interest Rates

Monthly Averages

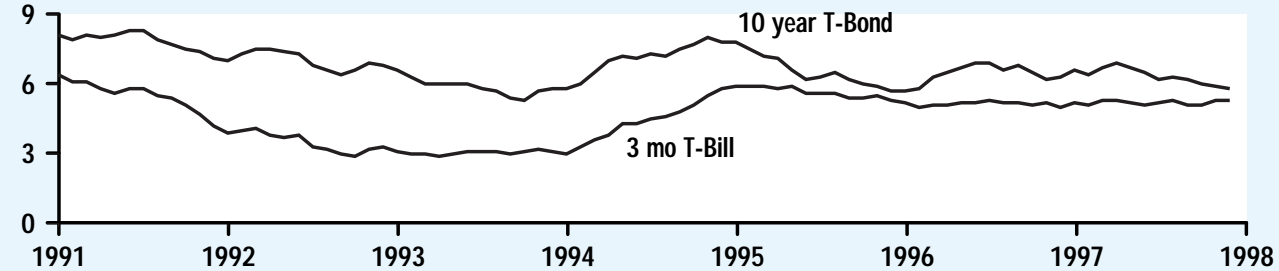

M2

Percent Change From Year Ago

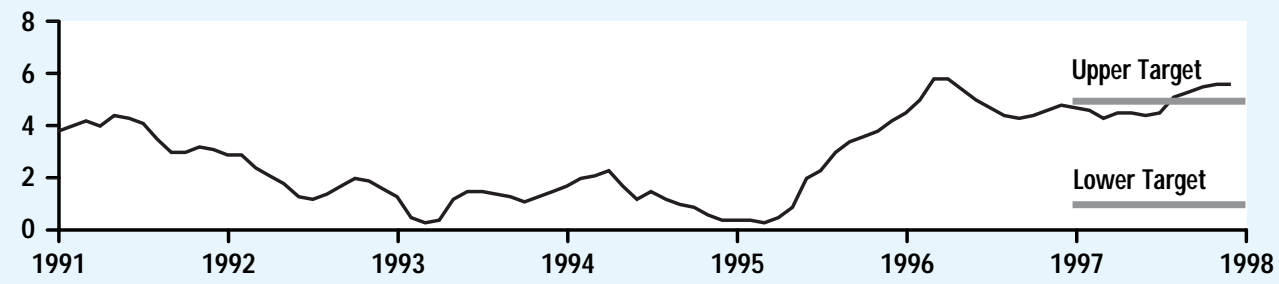

Real and Nominal Federal Funds Rate Monthly Averages

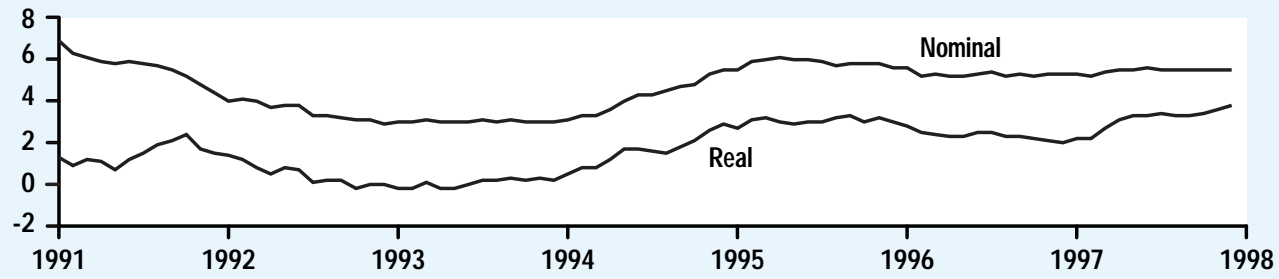




\section{REVIEW}

SEPTEMBER/ OCTOBER 1998

\section{Table 1}

The U.S. Economy in 1997

\begin{tabular}{|c|c|c|c|c|}
\hline Period & Real GDP & Inflation - CPI & $\begin{array}{l}\text { Nonfarm Business } \\
\text { Output per Hour }\end{array}$ & Unemployment Rate \\
\hline $\begin{array}{l}1997 \\
1948-1997 \\
1948-1969 \\
1970-1997\end{array}$ & $\begin{array}{l}3.7 \\
3.5 \\
4.5 \\
2.8\end{array}$ & $\begin{array}{l}1.7 \\
3.9 \\
2.2 \\
5.3\end{array}$ & $\begin{array}{l}2.1 \\
2.1 \\
3.2 \\
1.4\end{array}$ & $\begin{array}{l}5.0 \\
5.7 \\
4.7 \\
6.6\end{array}$ \\
\hline
\end{tabular}

Note: Real GDP and Inflation are fourth quarter over fourth quarter growth rates.

\section{AGGREGATE SUPPLY}

1997 marked the sixth year of the current expansion. As summarized in Figure 1 and Table 1, the economy showed remarkable strength and lower inflation during the year. Real Gross Domestic Product (GDP) grew 3.7 percent between the fourth quarter of 1996 and the fourth quarter of 1997. The civilian unemployment rate fell steadily throughout the year, starting the year at 5.1 percent and finishing at 4.3 percent. When compared to 1996, all measures of inflation were lower in 1997. The Consumer Price Index (CPI) rose a scant 1.7 percent in 1997, after rising 3.3 percent in 1996, and the Producers Price Index fell 1.2 percent during 1997.

The strength of the economy and lower inflation made it more difficult to formulate appropriate policy because they implied aggregate supply factors had affected the economy. An increase in demand produces higher prices and higher output, whereas an increase in supply generates lower prices and higher output. Since the data showed that output and inflation were moving in opposite directions, aggregate demand analysis was not sufficient to determine how much inflationary pressures existed in the economy. The FOMC, therefore, discussed factors that affected aggregate supply. There were several candidates: job insecurity, oil prices, slow growth of health care expenses, increased competition (both domestic and international), technical changes to the $\mathrm{CPI}$, the lack of pricing power and increases in labor productivity. ${ }^{1}$

\section{Productivity}

Of the potential factors listed, labor productivity deserved careful consideration because it allows companies to produce more with a given amount of labor, thereby reducing the cost of production. Most likely all other factors were temporary. Although the observed higher productivity may have been temporary as well, it also had the potential to have a much longer effect on the economy. The May meeting's minutes noted,

Members focused on the possible role of faster-than-reported increases in productivity as a key explanation for the benign behavior of inflation in current circumstances...The ongoing development and spreading adoption of automated equipment along with the increasing skills and other infrastructure needed to use it effectively appeared to be creating growing efficiencies or synergies that were markedly enhancing productivity and enabling firms to hold the line on prices and maintain high profit margins.

The growth rates of productivity and investment were two striking features of the U.S. economy's performance in 1997. After languishing for decades, labor productivity of nonfarm businesses during 1997 grew at a rate near its post-war average (see Table 1) and followed a respectable performance in 1996. Labor productivity in the manufacturing sector grew even more quickly and had been 
strong since the end of the last recession. In addition, investment as a fraction of GDP continued to grow and reached its highest level since the end of World War II, adding to the economy's productive capacity. Investment in computers and other information technologies grew especially quickly during the year.

\section{AGGREGATE DEMAND}

Although falling inflation and rapid growth suggested a positive shift of aggregate supply, there were indications that aggregate demand had increased as well, and signaled a possible source of inflationary pressures. Growth of real GDP was strong during 1997 and came on the heels of strong growth during 1996. Real GDP surpassed its post-war average and also surpassed most estimates of the potential growth rate of GDP. M oreover, various factors that support aggregate demand showed strength throughout the year. Personal income, supported by large net job creation, grew rapidly throughout the year; household wealth increased substantially as the stock market continued to rise; and consumer confidence rose to record levels. All these factors provided the wherewithal for robust consumer spending. Businesses continued to invest as the cost of capital fell and profits rose, further adding to aggregate demand.

\section{Monetary Aggregates}

N early all economists believe excesive money growth causes inflation. As recently as the early 1990s, the behavior of M 2 was an important input into monetary policy. ${ }^{2}$ Unfortunately, the unexpected and persistent rise of $\mathrm{M} 2$ velocity during the early part of this decade diminished its relevance for monetary policy. ${ }^{3} 1997$ brought M2 back into the policy discussion as the velocity of M2 showed signs of stabilizing at a higher level.

During 1997, FOMC members noted the growth of M2 above or at the upper end of its target range, possibly signaling an expansionary monetary policy, thereby stimulating aggregate demand and fueling future inflation. Certainly, most measures of economic activity were high throughout the year, and asset prices rose sharply. But, could the monetary aggregates be trusted once again to send reliable signals about inflationary pressures? Such issues were most likely on the FOMC members' minds as they discussed policy. But in the end, the committee decided to watch the aggregates carefully but sought other indicators of aggregate demand pressures.

....any tendency for growth of the monetary aggregates to move outside the Committee's ranges would not in itself call for a policy adjustment but would continue to be interpreted in the context of a broad range of business and financial developments bearing on the prospective performance of the overall economy.

...the period of more predictable M 2 and $\mathrm{M} 3$ behavior was still relatively brief and such behavior had occurred at a time of generally settled conditions in financial markets and the overall economy. The prospective performance of these aggregates in periods of rapid changes in financial and economic conditions was still an open question, and in light of the uncertainties that were involved the members concluded that it would be premature to place increased reliance on them in the conduct of policy.

\section{Resource Constraints}

So, the FOMC turned to the other traditional indicator of excess aggregate demand and inflationary pressures: resource constraints, which embody the notion that prices increase when demand exceeds supply. Two notable and somewhat related concepts of resource constraints are measured by the Phillips curve and the difference between actual and potential GDP.

The Phillips curve suggests that the amount of slack in the labor market

\footnotetext{
2 The Full Employment and Balanced Growth Act of 1978, also known as the HumphreyHawkins Act, requires the Federal Reserve to report target ranges for monetary aggregates to Congress. Pakko (1995) discusses the role of monetary aggregates as intermediate targets of monetary policy.

${ }^{3}$ Ritter (1993) discusses the instability of the signals from monetary aggregates during the early 1990 s.
} 
${ }^{4}$ Estimates of NAIRU also consider other factors like demographics. Gordon (1997) discusses recent developments and estimates of NAIRU. Staigler, Stock, and Watson (1997) suggest that the uncertainty of a NAIRU estimate is quite large, perhaps too large for policy makers.

${ }^{5}$ Under certain conditions these two relationships may be mapped one-to-one onto each other. Okun's law is one such empirical relationship between the output gap and employment gap. It states that a 1 percentage point drop in unemployment is associated with a 3 percentage point increase in output. effects prices in the short run by affecting production costs. Strong aggregate demand increases demand for labor and thus increases wages. Rising labor costs increase the cost of production which firms pass along to consumers as higher prices. Although price measures did not show higher inflation in 1997, the unemployment rate fell substantially, many new jobs were created and several measures of labor costs, including employment cost index, accelerated. The February FOMC minutes noted,

If labor markets remained under pressure, nominal compensation costs were likely to pick up at some point as one-time savings in worker benefit costs ran out and as workers became less willing to trade off lower wages for increased security; such a development would foster increases in labor costs that ultimately would feed through to higher prices.

Economists often translate the idea into a non-linear relationship between unemployment and inflation by estimating a threshold beyond which inflation accelerates. This measure is called NAIRU,

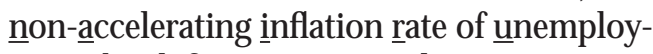
ment; by definition, unemployment rates above (below) NAIRU are associated with accelerating (decelerating) inflation. Most estimates of NAIRU were near 5.5 percent. ${ }^{4}$

The pace of economic activity produced strong employment growth and thus a lower unemployment rate. At the end of 1996, the unemployment rate was 5.3 percent-a rate below most estimates of NAIRU - and it fell steadily to 4.7 percent by the end of 1997. Moreover, the unemployment rate during 1997 was below the post-war average and significantly below the average for the post-1970 era.

The other measure of resource constraint is the gap between actual and potential GDP. The idea is similar to the Phillips curve with potential GDP replacing NAIRU. ${ }^{5}$ Like the difference between the unemployment rate and NAIRU, the difference between actual and potential GDP measures strength of demand relative to supply. The measure suggests that if aggregate demand grows more rapidly than an economy's ability to produce, inflationary pressures develop. If the growth of real GDP is above (below) that of potential GDP, inflation accelerates (decelerates). Chairman Greenspan noted in his July HumphreyHawkins testimony, "[W ]e endeavor to prevent strains from developing in our economic system, which long experience tells us produce bottlenecks, shortages, and inefficiencies. These eventually create more inflation, which undermines economic expansion and limits the longer term potential of the economy."

Economists often characterize an economy's productive capacity using an aggregate production function that has two components: labor and labor productivity. So, an estimate of potential GDP requires estimates of those two factors. The longrun growth rate of the labor force equals the growth rate of the population, currently about 1 percent. The other variable, labor productivity, is much harder to forecast because it incorporates factors such as the rate of net capital accumulation and technological change. One simple guess at the growth rate of labor productivity uses a long-run historical average as an estimate of the growth of labor productivity. Labor productivity growth has averaged 1.4 percent since 1970. Combining the population growth rate and the recent growth rate of labor productivity yields a potential growth rate of the U.S. economy of 2.4 percent, near most estimates of potential GDP growth.

\section{LONGEVITY AND LAGS}

Complications introduced by potential shifts of aggregate supply were compounded by uncertainty about how long such aggre gate supply enhancing factors would last. If the productivity continued to grow rapidly, potential GDP would be higher. Perhaps they would last as long as those factors possibly affecting aggregate demand. If the aggregate supply and demand factors had similar durations, perhaps no monetary policy response was necessary.

Determining the duration of such changes may be easy, in hindsight, but it is 
difficult to do while one is in the midst of them. As Chairman Greenspan stated in his July testimony before Congress,

We do not now know, nor do I suspect can anyone know, whether current developments are part of a once or twice in a century phenomenon that will carry productivity trends nationally and globally to a new higher track, or whether we are merely observing some unusual variations within the context of an otherwise generally conventional business cycle expansion.

Still, advocates of the long-lived, productivity-increase hypothesis saw recent developments in information technology and recent cost-cutting measures as the primary drivers of productivity gains. The proponents of the structural change viewpoint noted the persistent growth of investment, especially in information technologies. ${ }^{6}$ Chairman Greenspan speculated in his July Humphrey-Hawkins testimony, "W hat we may be observing in the current environment is a number of key technologies, some even mature, finally interacting to create significant new opportunities for value creation."

The committee members also had to consider monetary policy lags because any policy actions might have accentuated economic fluctuations rather than dampening them, if the effects of policy coincided with reversion to normal levels of economic activity. So, if the aggregate demand and supply factors were short lived, they would dissipate before effects of monetary policy would take hold. Chairman Greenspan noted, ${ }^{7}$

The Federal Reserve's policy actions, the evidence demonstrates, affect the financial markets immediately, but work with a significant lag of several quarters or more on output and employment, and even longer on prices. Too often in the past, policy makers responded late to unfolding economic developments and found they were far behind the curve, so to speak; as a result, their policy actions were creating or accentuating business cycles, rather than sustaining expansion.

This lagged effect of policy also implied that the FOMC had to make policy decisions before measured inflation rose and all evidence of aggregate demand and supply factors were available. The Chairman continued in the same speech,

Those who wish for us, in the current environment, to await clearly visible signs of emerging inflation before acting are recommending we return to a failed regime of monetary policy that cost jobs and living standards. I wish it were otherwise, but there is no alternative to basing policy on what are, unavoidably, uncertain forecasts.

\section{SUMMARY OF \\ FOMC MEETINGS}

The struggle to find answers to the two questions posed by Chairman Greenspan and the FOMC's decisions about the appropriate course of monetary policy was evident in the minutes of the eight meetings. (Table 2 summarizes the outcomes of the meetings.) Throughout the year, the incoming data showed that the growth rates of monetary aggregates were near the upper end of their targets, growth of real output was greater than that of potential output, and the unemployment rate was below most estimates of NAIRU. All of these factors hinted at inflationary pressures. Yet, inflation continued to fall throughout the year.

\section{February 4-5}

The first FOMC meeting of 1997 set the tone for most of the year. Incoming information suggested that economic activity had increased substantially during the fourth quarter of 1996. The Commerce Department's advance estimate of real GDP growth in the fourth quarter of 1996 showed the economy grew at a 4.7 percent annual rate. The unemployment
${ }^{6}$ Interestingly, the discussions about changes in productivity were not noticeable in most estimates of the growth rate of potential GDP. If higher productivity growth is long lived, potential GDP should grow faster than 2 to $2 \%$ percent. Yet, forecasters expected real GDP growth to moderate and grow at 2 to $2 \% / 2$ percent within 12 to 18 months. The February Humphrey-Hawkins report's central tendency of real GDP growth for 1997 was 2 to $21 / 4$ percent. The Blue Chip, Congressional Budget Office, and Office of Management and Budget all forecasted similar growth rates of potential GDP.

${ }^{7}$ Chairman Greenspan gave the speech at the Haskins Partners Dinner of the Stern School of Business, New York University, on May 8, 1997. 


\section{Table 2}

Summary of FOMC Decisions

\begin{tabular}{lccc} 
Date & $\begin{array}{c}\text { Directive for } \\
\text { Reserve Pressure }\end{array}$ & Intermeeting Stance & Dissent \\
\hline $2 / 4-5$ & maintain & asymmetric (tighter) & none \\
$3 / 25$ & increase slightly & symmetric & none \\
$5 / 20$ & maintain & asymmetric (tighter) & Broaddus \\
$7 / 1-2$ & maintain & asymmetric (tighter) & none \\
$8 / 19$ & maintain & asymmetric (tighter) & none \\
$9 / 30$ & maintain & asymmetric (tighter) & none \\
$11 / 12$ & maintain & asymmetric (tighter) & Broaddus \\
$12 / 16$ & maintain & symmetric & Broaddus
\end{tabular}

rate was at 5.3 percent and various measures of labor compensation also accelerated. At the same time, inflation showed little change in its trend.

The members expected the pace of economic activity to slow and acknowledged potential price pressures from high rates of resource utilization, although recent behavior deviated from historical patterns. The committee decided,

an unchanged policy seemed appropriate with inflation still quiescent, with few signs of emerging price pressures, with growth in economic activity seen as likely to moderate appreciably from the unexpectedly strong and unsustainable pace of the fourth quarter.

One potential dampening factor was the stock market. Surprisingly, the committee viewed the stock market as a source of potential strength or weakness for the economy. The continuing increase in equity prices added significantly to consumer's wealth and therefore provided the wherewithal to support higher spending.

${ }^{8}$ The small size of the policy action and lack of any other changes during the remainder of the year might have reflected the uncertainty expressed by the committee. Brainard (1967) argued that policy made under uncertainty should be smaller than one made with full information. strength in economic activity over the closing months of 1996 was persisting in 1997." Moreover, the committee and forecasters expected the economy to slow, but "they felt that substantial uncertainty surrounded the timing and extent of such slowing in the quarters ahead." Still, the continued strength of the economy increased the risk of inflation, given the al ready high levels of resource utilization. "However, the risks of a rise in inflation down the road had increased appreciably as a result of the strength of aggregate demand and the increase in pressures on resources that likely would accompany it absent a firming in financial conditions."

These concerns led the committee to act preemptively by raising the intended federal funds target by 25 basis points to 5.5 percent. This would be the only change of the year. ${ }^{8}$

In this situation, they saw a clear need for a preemptive policy action that would head off any pickup of inflation, and it was noted that a shift to a tighter policy stance would seem to pose little risk to the expansion. Indeed, by countering any tendency for inflation to rise and for higher inflation expectations to become embedded in financial markets and economic decision-making more generally, such action would help head off a more abrupt economic slowing, or even a downturn, and thereby would

\section{March 25}

The data prior to the March 25th meeting showed "widespread statistical and anecdotal evidence that the surprising diminished household wealth, and had the opposite effect on spending.

FEderal RESERVE BANK OF ST. LOUIS 
help sustain the expansion and preserve the firm labor markets and their associated benefits. ${ }^{9}$

The FOMC released an unusually long statement after the meeting to explain its action: ${ }^{10}$

The Federal Open Market Committee decided today to tighten money market conditions slightly, expecting the federal funds rate to rise $\frac{1}{4}$ percentage point to around $5 \frac{1}{2}$ percent.

This action was taken in light of persisting strength in demand, which is progressively increasing the risk of inflationary imbalances devel oping in the economy that would eventually undermine the long expansion.

In these circumstances, the slight firming of monetary conditions is viewed as a prudent step that affords greater assurance of prolonging the current economic expansion by sustaining the existing low inflation environment through the rest of this year and next. The experience of the last several years has reinforced the conviction that low inflation is essential to realizing the economy's fullest growth potential.

No change was made in the Federal Reserve discount rate, which remains at 5 percent.

\section{May 20}

The economy showed some signs of slowing, although the committee members believed there was underlying strength in the economy. Consumer spending rose at a slower pace as did increases in payroll employment. Industrial production was unchanged between March and April. Still, they found the high resource utilization rates and low inflation nexus puzzling.

[T] he members found it very difficult to account for the surprisingly benign behavior of inflation in an economy that had been operating at a level approximating full employment, indeed, possibly somewhat above sustainable full employment in labor markets in the view of a number of members, especially taking into consideration the recent further decline in the unemployment rate. On the basis of historical patterns, any overshooting of full employment would be expected to generate rising inflation over time. Although increases in labor compensation had been trending higher, these pressures were muted and had not shown through to prices.

In light of continuing uncertainty and the absence of inflation, the committee decided not to change the federal funds target. Not all were in agreement, however.

Mr. Broaddus dissented because he believed that the strength of investment demand, due possibly to an increase in the trend growth rate of productivity, required somewhat higher real interest rates to prevent inflationary pressures from developing. He was concerned that, with the economy al ready operating at a high level and labor markets apparently very tight, any increase in such pressures might be costly to reverse and might reduce the credibility of the Committee's longer run strategy of promoting maximum sustainable growth by fostering price level stability. He also believed that the risk to the economy of a moderate further tightening was small given the apparent momentum of aggregate economic activity.

\section{J uly 1-2}

Incoming data suggested that economic activity during the second quarter was substantially slower than the first. The committee interpreted this as a general return to the potential growth rate of the economy over the following six

\footnotetext{
${ }^{9}$ Friedman (1968) and Phelps (1968) show that a simple Phillips curve misses the importance of expectations in determining any relationship between unemployment and inflation. Lucas (1973) extends the analysis by incorporating rational expectations which showed that a stable relationship between inflation and unemployment need not exist if agents rationally anticipate policy maker's actions. Kyland and Prescott (1977), Calvo (1978), Kreps and Wilson (1982), Barro and Gordon (1983) and Barro (1986) show the importance of reputation and time inconsistency in determining the welfare costs of monetary policy actions.

${ }^{10}$ Prior to 1994 the committee did not make any announcements about policy decisions.
} 
quarters. Still, the members viewed faster growth as a risk to their forecast. The committee also discussed productivity improvements.

More fundamentally, [the low inflation] presumably also involved the favorable effects on production costs of widespread business restructuring and the large volume of investment in more productive technology in recent years, the impact of both factors on the job security concerns of workers and their willingness to accept reduced increases in compensation, and the effects of an intense degree of competition among domestic and foreign producers in U.S. markets. With regard to the possibility that more robust productivity increases would be holding down production costs, it was noted that a surge in economic activity, such as had occurred in late 1996 and early 1997, tended to be accompanied by above-trend gains in productivity. A slower pace of economic growth in the second quarter and beyond might provide an opportunity to assess whether productivity increases were on a clear up trend and could help to explain the favorable behavior of prices over an extended period. In any event, it was too early to reach any firm conclusion on this issue or the broader question of whether or when a rise in inflation might materialize under anticipated economic conditions.

The FOMC members also discussed their outlook for 1997 and 1998. Their forecasts for real GDP growth for 1997 and 1998 showed central tendencies of 3 to $3 \frac{1}{4}$ percent and 2 to $2 \frac{1}{2}$ percent, respectively. They also saw the unemployment rate within a range of $4 \frac{3}{4}$ to 5 percent for both years, and CPI inflation within $2 \frac{1}{4}$ to $2 \frac{1}{2}$ percent for 1997 and $2 \frac{1}{2}$ to 3 percent for 1998.

${ }^{11}$ The minutes from the May 20 meeting also make a passing reference to high real interest rates.

\section{A ugust 19}

A new concern for the committee surfaced during this meeting, the growth of inventories.
The uncertain prospects for inventory investment were a dominant factor in the outlook for economic activity over the nearer term. The accumulation of inventories had been unusually high in the second quarter according to the available evidence. There was no broad sense of an undesired buildup, but the rate of inventory investment would have to be reined in if an overhang were to be averted. A concern in this regard was that the apparent upturn in final demand, particularly if it proved to be somewhat stronger than currently expected, and related business optimism about sales prospects might well result in a further buildup of inventories at a relatively rapid rate. While such a development was not viewed as the most likely outcome and, indeed, less-than-projected strength in the inventory sector could not be ruled out, relatively rapid inventory accumulation in the context of persisting above-trend growth in final demand would generate additional pressure on resources and heighten the risks of accelerating inflation.

The discussion during the meeting also mentioned high, real short-term interest rates as a possible damper on activity. ${ }^{11}$ The Fisher equation states that nominal and real interest rates differ by expected inflation. Using actual inflation as a proxy for expected inflation, the real federal funds rate rose sharply during 1997. Indeed Chairman Greenspan would later acknowledge the possibility of a passive tightening in his February 1998 Humphrey-Hawkins testimony.

Although the nominal federal funds rate was maintained after $M$ arch, the apparent drop in inflation expectations over the balance of 1997 induced some firming in the stance of monetary policy by one important measure - the real federal funds rate, or the nominal federal funds rate less a proxy for inflation expectations. Some analysts have dubbed the contribution of the reduc- 
tion in inflation expectations to raising the real federal funds rate a 'passive' tightening, in that it increased the amount of monetary policy restraint in place without an explicit vote by the FOMC. While the tightening may have been passive in that sense, it was by no means inadvertent. M embers of the FOMC took some comfort in the upward trend of the real federal funds rate over the year and the rise in the foreign exchange value of the dollar because such additional restraint was viewed as appropriate given the strength of spending and building strains on labor resources.

The directive issued to the 0 pen $M$ arket Desk at this meeting made an explicit reference to the intended federal funds target for the first time. Previous directives only mentioned possible changes to reserve pressure.

\section{September 30}

The pace of economic activity accelerated again after a slow second quarter. Still, the committee delayed making any further changes in policy.

There were, nonetheless, a number of reasons for delaying a tightening of policy. The behavior of inflation had been unexpectedly benign for an extended period of time for reasons that were not fully understood. Forecasts of an upturn in inflation were therefore subject to a considerable degree of uncertainty, and the expansion of economic activity could still slow to a noninflationary pace. M embers also commented that a policy tightening was not anticipated at this time and such an action might therefore have unintended adverse effects on financial markets. Members recognized that from the standpoint of the level of real short-term interest rates, monetary policy could al ready be deemed to be fairly restrictive. Several noted, however, that credit from a wide variety of lenders appeared to be amply available in financial markets on favorable terms, perhaps overly so in present circumstances, and some also noted that the strength in the broad measures of money in recent months suggested that policy was not restraining liquidity or financial conditions more generally. In the course of the Committee's discussion of these diverging considerations, a consensus emerged for maintaining a steady policy course at this time, but members also expressed the need for a heightened degree of vigilance as they continued to assess ongoing developments for signs that inflation might intensify in the future.

\section{November 12}

The continued strength of the economy continued to worry the FOMC. "[T] he members agreed that there remained a clear risk of additional pressures on al ready tight resources and ultimately on prices that could well need to be curbed by tighter monetary policy." But they found themselves more concerned about a new development, a crisis in Asia. ${ }^{12}$ "Turmoil in Asian financial markets and economies would tend to damp output and prices in the United States. To date, it appeared that the effects on the U.S. economy would be quite limited, but the ultimate extent of the adjustment in Asia was unknown, as was its spillover to global financial markets and to the economies of nations that were important U.S. trading partners." 13

In light of the uncertainty and absence of inflation the committee decided to leave policy unchanged. But once again,

Mr. Broaddus dissented because he believed that a modest tightening of policy would be prudent in view of the recent strength in aggregate demand for goods and services; such demand appeared to be growing considerably more rapidly than the sustainable rate at which it could be supplied without an increase in inflation. While he rec-
${ }^{12}$ The crisis in Asia started several months earlier in early summer with the devaluation of the Thai baht.

${ }^{13}$ There was considerable uncertainty about the effects of the crisis. Several forecasts issued at the end of the year showed slower growth in the Asian countries. The crisis' effect on the U.S. centered on two effects. First, forecasters expected export of goods produced in the U.S. to the affected countries to decrease, but direct trade between the U.S. and the affected countries was relatively small. Second, the crisis might induce slower growth in Japan and other countries that were larger trading partners of the U.S. aS demand for their exports fell. This created another channel for the Asian crisis to affect the U.S. economy. 
ognized that a tightening at this meeting presented risks in view of recent financial and economic developments in East Asia, he believed these risks were outweighed by the risk that policy would have to be tightened more aggressively if action were delayed, demand remained robust, and the recent apparent reduction in inflationary expectations were reversed. The negative impact on economic activity in such circumstances would be markedly greater than if a more modest action were taken at this meeting.

\section{December 16}

The year ended much as it started. "[M ] embers commented on indications that growth in economic activity had remained solid and that inflation had continued to be surprisingly low."

More importantly, the Asian crisis continued to worry the committee.

However, the effects of the persisting turmoil in Asian financial markets were likely to moderate the pace of expansion, though the extent of this effect was difficult to judge. The ongoing turbulence since the last Committee meeting, which included further noticeable increases in the dollar against the currencies of affected countries, likely would have a somewhat greater damping effect on output and prices in the United States than previously had been anticipated. Exports to many Asian countries, and possibly to other U.S. trading partners whose economies might be adversely affected by the spillover effects of developments in Asia, would be reduced, and declines in import prices would ease inflation pressures. However, the ultimate extent of the adjustment in Asian economies remained unknown, and more substantial downward pressure on the economies of the United States and its trading partners could not be ruled out.
The uncertainty surrounding the economic outlook led the committee to change the asymmetric, intermeeting directive that had been in place for most of the year.

A majority of the members indicated a preference for a shift to a symmetrical directive even though many continued to anticipate that the next policy move was likely to be in a tightening direction. They noted that while the probability of any policy change in the near term was very low, uncertainties in the outlook had increased, and they could not rule out the possibility that the next change might be in the direction of some easing if, contrary to current expectations, the turmoil in Asia were to intensify to the extent that it seemed likely to exert very substantial effects on the U.S. economy. A symmetric directive would position the Committee to respond flexibly in either direction to unanticipated developments in the period ahead.

But all were not in agreement.

Mr. Broaddus dissented because he continued to believe that a modest tightening of policy would be prudent in light of the apparent persisting strength in aggregate demand for goods and services. He recognized the case for holding policy steady given recent developments in East Asian economies and financial markets; he believed, however, that a slight firming at this meeting would provide valuable insurance against the risk that demand growth might remain above a sustainable trend and require a sharper policy response later. He thought further that the potential benefits of this insurance outweighed the risk that such an action would have a significant negative impact on U.S. economic activity. He also believed that signaling a greater willingness to tolerate modest policy adjustments in response to emerging developments would foster more flexi- 
ble movements in longer term financial markets, and specifically enable longer term interest rates to play their traditional role as automatic stabilizers for the economy more effectively.

\section{CONCLUSION}

Although the economic performance of the U.S. economy in 1997 was very good, it was in at least one respect troubling for the FOMC. Traditional signals of inflation - rapid money growth and high levels of economic activity- were not accompanied by higher inflation. Rather, inflation fell steadily throughout the year.

The committee put forth several hypotheses for the subdued inflation but found the situation puzzling, nevertheless. Compounding the problem, the members did not know how long such dampening factors would last, and thus did not know if policy actions would exacerbate a foreseen slowdown of the economy. In the end the FOMC changed the intended federal funds target once and then searched anxiously for the answers to the conundrum they faced in 1997.

\section{REFERENCES}

Barro, Robert J. "Reputation in a Model of Monetany Policy with Incomplete Information," Journal of Monetary Economics (January 1986), pp. 3-20.

\footnotetext{
_ _ and David Gordon. "A Positive Theory of Monetary Policy in a Natural Rate Model," Joumal of Political Economy (August 1983), pp. 598-610.

Brainard, William. "Uncertainty and the Effectiveness of Policy," American Economic Review (May 1967), pp. 411-425.

Calvo, Guillermo. "On the Time Consistency of Optimal Policy in a Monetary Economy," Econometrica (November 1978), pp. 1411-1428.

Friedman, Milton. "The Role of Monetary Policy," American Economic Review (March 1968), pp. 1-17.

Gordon, Robert J. "The Time-Varying NAIRU and Its Implication for Economic Policy," Journal of Economic Perspective (Winter 1997), pp. 11-32.

Kreps, David, and Robert Wilson. "Reputation and Imperfect Information," Journal of Economic Theory (August 1982), pp. 253-279.
}

Kydland, Finn E., and Edward C. Prescott. "Rules Rather than Discretion: The Inconsistency of Optimal Plans," Journal of Political Economy (June 1977), pp. 473-491.

Lucas, Robert E., Jr. "Some International Evidence on Output-Inflation Tradeoffs," American Economic Review (J une 1973), pp. 326-334.

Pakko, Michael R. "The FOMC in 1993 and 1994: Monetary Policy in Transition," this Review (March/ April 1995), pp. 3-25.

Phelps, Edmund S. "Money-Wage Dynamics and Labor Market Equilibrium," Journal of Political Economy (August 1968), pp. 678-711.

Ritter, Joseph A. "The FOMC in 1992: A Monetary Conundrum," this Review (Mayl June 1993), pp. 31-49.

Staiger, Douglas, James H. Stock, and Mark W. Watson. "The NAIRU, Unemployment and Monetary Policy," Journal of Economic Perspective (Winter 1997), pp. 33-49. 


\section{BFHEIII \\ SEPTEMBER/ OCTOBER 1998}

FEDERAL RESERVE BANK OF ST. LOUIS 